\title{
Evaluation of the Knowledge and Attitudes of Patients Admitted to COVID-19 Outpatient Clinic about Traditional and Complementary Medicine
}

\section{COVID-19 Polikliniğine Başvuran Hastaların Geleneksel ve Tamamlayıcı Tıp Uygulamaları Hakkında Bilgi ve Tutumlarının Değerlendirilmesi}

\author{
Disa Çetin Kargın \\ Konya Numune Hospital, Department of Family Medicine, Selçuklu, Konya, Turkey
}

\begin{abstract}
Objective: During the coronavirus-19 (COVID-19) pandemic, an effective treatment method for the treatment and prevention of the disease has not been determined yet. Promising results have been achieved in the treatment of COVID-19 with a holistic approach in addition to conventional medical methods in traditional and complementary medicine practices (TCM), which are increasing in popularity today. This study was aimed to evaluate the view, attitude and behavior of the participants who applied with the suspicion of COVID-19 in the treatment and protection of COVID-19.
\end{abstract}

Material and Method: A 12-question questionnaire was applied to the volunteers among the patients who applied to the outpatient clinic with the suspicion of COVID-19. Participants were asked multiple choice questions questioning their beliefs and previous experiences in TCM and their views, beliefs and behaviors in the treatment and prevention of COVID-19.

Results: $145(77,5 \%)$ of the participants say that they have knowledge about TCM and $71,7 \%$ of them believe in TCM applications. In addition, $33.2 \%$ of the participants have applied to TCMapplications before. During the pandemic period, phytotherapy $(22,46 \%)$ was the second cupping treatment $(12,83 \%)$, which was the most beneficial application. Although $27,7 \%$ of the participants thought that TCM would not be more beneficial than conventional COVID-19 drugs, 19,79\% believed that it would be beneficial with routine medications.

Conclusion: In Turkey increased knowledge and beliefs about TCM applications in all walks though the COVID-19 in the treatment and prevention holistic approach to conventional medicine has still not accepted enough belief in society.

Keywords: Coronavirus, traditional medicine, holistic approach, pandemic
Öz

Amaç: Koronavirüs-19 (COVID-19) pandemisi sürecinde hastalığın tedavisinde ve korunmada halen etkin bir tedavi metodu belirlenememiştir. Günümüzde popülaritesi giderek artan geleneksel ve tamamlayıcı tıp uygulamalarında (GETAT) klasik tıbbi yöntemlere ilaveten bütüncül yaklaşımla COVID-19 tedavisinde umut verici sonuçlar elde edilmiştir. Kesitsel tipteki bu çalışmada COVID-19 şüphesi ile başvuran katılımcıların COVID-19 tedavi ve korunmasında GETAT'a bakışı, tutum ve davranışlarının değerlendirilmesi amaçlanmıştır.

Gereç ve Yöntem: COVID-19 şüphesi ile polikliniğe başvuran hastalardan gönüllü olanlara 12 soruluk anket yapılmıştır. Katılımcılara GETAT'a inanışları ve daha önceki deneyimleri ile COVID-19 tedavi ve korunmasında GETAT'a bakışları, inanışları ve davranışlarını sorgulayan çoktan seçmeli sorular yöneltilmiştir.

Bulgular: Katıımcıların 145 (\%77,5)'iGETAThakkında bilgisini olduğunu ve \%71,7'si de GETAT uygulamalarına inandığını söylemektedir. Ayrıca katılımcıların \%33,2'si ise daha önce GETAT uygulamalarına başvurmuştur. Pandemi döneminde en sık faydalı olduğu düşünülen uygulama fitoterapi $(\% 22,46)$, ikinci kupa tedavisi $(\% 12,83)$ olmuştur. Katılımcıların \%27,7'si GETAT'ın klasik COVID-19 ilaçlarından daha faydalı olmayacağını düşünmesine rağmen \%19,79 katılımcı ise rutin ilaçlarla birlikte faydalı olacağına inanıyordu.

Sonuç: Türkiye'de her kesimde GETAT uygulamaları hakkında bilgi ve inanış artmış olsa da COVID-19 tedavisi ve korunmasında klasik tıbba bütüncül yaklaşımlarına olan inanış halen toplumda yeterli kabul görmemiştir.

Anahtar Kelimeler: Koronavirüs, geleneksel tıp, bütüncül yaklaşım, pandemi 


\section{INTRODUCTION}

The new type of coronavirus (COVID-19) outbreak, which has spread rapidly since December 2019 and has become a pandemic, remains the leading medical health problem for the world. Despite all efforts, there is still no effective treatment method. Therefore, treatments often focus on the treatment of symptoms and prevention of transmission of the disease. These uncertainties in its treatment have played a role in the orientation of some patients towards traditional and alternative therapies, especially medicinal plants. As a matter of fact, numerous studies have been published examining the effects of phytotherapy and ozone therapy on COVID-19. [1-3] In fact, positive effects of acupuncture, phytotherapy (zinc, garlic, green tea, etc.) and systemic ozone treatment on COVID-19 complications and the course of the disease have been reported. ${ }^{[4-9]}$ It is not yet clear what the trend is like in the COVID-19 pandemic and the patients' view of these practices in the treatment of COVID-19 is not yet clear, especially in eastern countries where belief in traditional medicine is widespread.

To evaluate the views, experiences and attitudes of patients who apply to traditional and complementary medicine practices (TCM) frequently referred to in the COVID-19 pandemic with suspicion of COVID-19 and their attitudes and opinions about its effectiveness in the treatment of COVID-19.

\section{MATERIAL AND METHOD}

\section{Universe and sampling}

The study is of a cross-sectional type and people over the age of 18 constitute the universe of the study. Within the scope of pre-study research on COVID-19, scientific research permission was obtained from the Ministry of Health and ethical approval numbered 2021/005 from KTO Karatay University.

\section{Participant Selection}

This study was performed in accordance with the declaration of Helsinki protocol. Patients who applied to XXX Hospital COVID-19 outpatient clinics with suspicion of COVID-19 between November 2020 and January 2021 were asked to participate in the survey during the COVID-19 diagnostic tests and the volunteers were surveyed. A total of 214 participants were included in the study. $27(12.6 \%)$ of them who were incomplete or not consistently filled out in the questionnaire form were excluded in the study. The study was conducted with the data of 187 participants. Participants were randomly selected from all applicants on a voluntary basis regardless of age, gender and sociodemographic characteristics. All participants received voluntary questionnaires and informed consent forms for data protection.

\section{Survey Form}

In addition to sociodemographic factors in the study, a total of 12 questionnaires were applied that evaluated the participants' knowledge about TCM practices, awareness and TCM practices during the pandemic period (Form 1). Eight of the questions are multiple choice, three can be selected multiple options, and one is open-ended. The educational status of the participants was categorized in 5 different groups. The form, which was created to evaluate the sociodemographic characteristics of the participants, includes age, gender, educational status, working status. Occupations are collected in 6 main categories according to socioeconomic status. Participants were asked to choose information, attitudes, behaviors and attitudes and beliefs about TCM practices during the pandemic period in a multiple choice: 1-yes, 2- partly, 3-undecided, 4-no. In addition, TCM practices, which are frequently used to describe which TCM practices they applied to before and after the pandemic, are given to allow them to select multiple options. The study was conducted in the $1^{\text {st }}$ year of the COVID-19 pandemic and at a time when the positive effects of systemic ozone, acupuncture and mug treatment practices on COVID-19 were socially known.

\section{Statistical Analysis}

As a descriptive statistic; number, percentages, median, minimum, and maximum value; Chi-Square in single analyses, multiple logistic regression analysis was used in multiple analyses. SPSS 22.0 package program was used to evaluate the data.

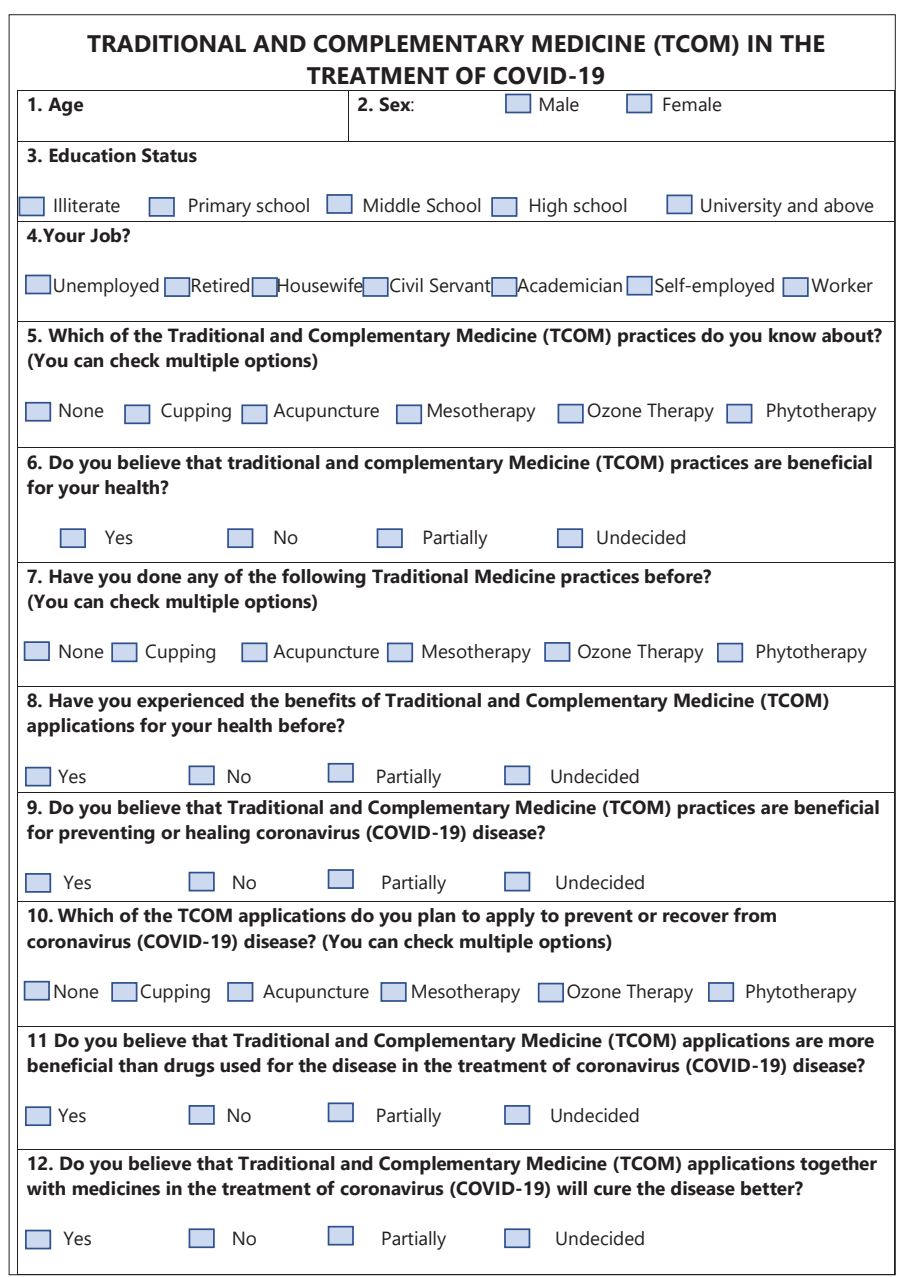

Form 1. Survey Form 


\section{RESULTS}

Sociodemographic data of the participants are given in Table 1. $63.6 \%$ of the participants are male and the average age is 36 . When evaluated according to educational status, it was found that only $2(1.07 \%)$ participants were literate, with the majority (33.16\%) studying in high school and above. According to the professions, $41.71 \%$ of the participants are in the working group and the civil servants (19.79\%) come in second place.

The majority of those who were familiar with TCM applications were women (86.7\%, $p=0.02 \%) .145$ (77.5\%) participants said they had information about TCM practices; participants with knowledge stated that they had the most knowledge about trophy treatment (35.3\%). In addition, $17.7 \%$ of respondents reported having information about more than one application.

\begin{tabular}{|c|c|c|c|}
\hline & & $\mathbf{n}$ & $\%$ \\
\hline \multirow{4}{*}{ Gender } & Female & 68 & 36.36 \\
\hline & Male & 119 & 63.64 \\
\hline & Literate & 2 & 1.07 \\
\hline & Primary school & 30 & 16.04 \\
\hline \multirow{6}{*}{$\begin{array}{l}\text { Education } \\
\text { Status }\end{array}$} & Secondary school & 34 & 18.18 \\
\hline & High School & 62 & 33.16 \\
\hline & University and above & 59 & 31.55 \\
\hline & Unemployed & 16 & 8.56 \\
\hline & Retired & 4 & 2.14 \\
\hline & Housewife & 30 & 16.04 \\
\hline \multirow{5}{*}{ Profession } & Officer & 37 & 19.79 \\
\hline & Academics & 5 & 2.67 \\
\hline & Self-employed & 17 & 9.09 \\
\hline & Workers & 78 & 41.71 \\
\hline & & Mean \pm SD & Min-max \\
\hline Age & & $36.00 \pm 10.07$ & $18-64$ \\
\hline
\end{tabular}

The mean age of patients with no knowledge of TCM practices was 36.53 \pm 10.09 , while the average age of those with knowledge of any of them was $36.29 \pm 9.55$ and was statistically similar $(p=0.882)$. Participants had similar knowledge levels about TCM practices based on their educational status and occupation ( $p=0.730, p=0.140$, respectively).

$71.7 \%$ of respondents said they believed TCM, but $6.4 \%$ said they did not. Participant's gender, educational status and occupation and their belief in TCM practices were similar $(p=0.155, p=0.451, p=0.938$, respectively). In addition, $57.2 \%$ of patients with knowledge about TCM practices believe in TCM.

$31.01 \%$ of respondents to any TCM practices; $2.13 \%$ have applied to more than one TCM practice. Most respondents (66.8\%) had never applied to any TCM practices before. Participants' gender, educational status and occupation and their application rates for TCM practices were similar $(p=0.638, p=0.161, p=0.535$, respectively).

Although the number of participants who previously benefited from TCM practices, did not see and were undecided was equal 27 (27.9\%), 30 (16.1\%) benefited in part from participating applications (Table 2). TCM practices was cup treatment where participants had the most knowledge (35.3\%) and applied most frequently (17.1\%). In addition, $33(16.7 \%)$ of the participants were familiar with two or more applications. More than half (50.27\%) of respondents believed TCM practices were beneficial. There was no difference between the gender, educational status and occupation of the participants and their previous benefits from TCM practices $(p=0.963, p=0.223, p=0.535$, respectively). Applications for TCM practices were found to be partially older (Figure 1).

\begin{tabular}{|c|c|c|c|c|c|}
\hline & & $\begin{array}{c}\text { Participant } \\
\text { n (\%) }\end{array}$ & $\begin{array}{l}\text { Male } \\
\text { n (\%) }\end{array}$ & $\begin{array}{c}\text { Female } \\
\text { n (\%) }\end{array}$ & $\mathbf{p}$ \\
\hline $\begin{array}{l}\text { Which of the TCM } \\
\text { practices do you } \\
\text { know about? }\end{array}$ & $\begin{array}{l}\text { None } \\
\text { Cupping } \\
\text { Acupuncture } \\
\text { Mesotherapy } \\
\text { Ozone Treatment } \\
\text { Phytotherapy } \\
\text { Cupping-Ozone Treatment } \\
\text { Cupping-Acupuncture } \\
\text { Cupping- Phytotherapy } \\
\text { Cupping-Ozone - Phytotherapy } \\
\text { Cupping-Acupuncture-Ozone } \\
\text { Cupping-Acupuncture-Phytotherapy } \\
\text { All }\end{array}$ & $\begin{array}{l}42(22.5) \\
66(35.3) \\
12(6.4) \\
3(1.6) \\
3(1.6) \\
28(15.0) \\
2(1.1) \\
9(4.8) \\
2(1.1) \\
2(1.1) \\
1(0.5) \\
11(5.9) \\
6(3.2)\end{array}$ & $\begin{array}{c}33(27.7) \\
40(33.6) \\
6(5.0) \\
1(0.8) \\
3(2.5) \\
14(11.8) \\
2(1.7) \\
5(4.2) \\
1(0.8) \\
0(0) \\
1(0.8) \\
8(6.7) \\
5(4.7)\end{array}$ & $\begin{array}{l}9(13.2) \\
26(38.2) \\
6(8.8) \\
2(2.9) \\
0(0) \\
14(20.6) \\
0(0) \\
4(5.9) \\
1(1.5) \\
2(2.9) \\
0(0) \\
3(4.4) \\
1(1.5)\end{array}$ & \\
\hline $\begin{array}{l}\text { Have you had any } \\
\text { of the TCM practices } \\
\text { done? }\end{array}$ & $\begin{array}{l}\text { None } \\
\text { Cupping } \\
\text { Acupuncture } \\
\text { Mesotherapy } \\
\text { Ozone Treatment } \\
\text { Phytotherapy } \\
\text { Acupuncture-Phytotherapy } \\
\text { Cupping-Acupuncture-Phytotherapy }\end{array}$ & $\begin{array}{c}125(66.8) \\
32(17.1) \\
6(3.2) \\
5(2.7) \\
4(2.1) \\
11(5.9) \\
1(0.5) \\
3(1.6) \\
\end{array}$ & $\begin{array}{c}81(68.1) \\
20(16.8) \\
4(3.4) \\
2(1.7) \\
3(2.5) \\
7(5.9) \\
1(0.8) \\
1(0.8)\end{array}$ & $\begin{array}{l}44(64.7) \\
12(17.6) \\
2(2.9) \\
3(4.4) \\
1(1.5) \\
4(5.9) \\
0(0) \\
2(2.9)\end{array}$ & \\
\hline $\begin{array}{l}\text { Do you believe that } \\
\text { TCM practices are } \\
\text { beneficial for your } \\
\text { health? }\end{array}$ & $\begin{array}{l}\text { Yes } \\
\text { Partially } \\
\text { I'm undecided. } \\
\text { No }\end{array}$ & $\begin{array}{c}94(50.27) \\
40(21.39) \\
41(21.93) \\
12(6.42)\end{array}$ & $\begin{array}{l}63(52.9) \\
25(21.0) \\
21(17.6) \\
10(8.4)\end{array}$ & $\begin{array}{c}31(45.6) \\
15(22.1) \\
20(29.4) \\
2(2.9)\end{array}$ & 0.156 \\
\hline $\begin{array}{l}\text { TCM practices has } \\
\text { you benefited from } \\
\text { its applications for } \\
\text { your health? }\end{array}$ & $\begin{array}{l}\text { Yes } \\
\text { Partially } \\
\text { I'm undecided. } \\
\text { No }\end{array}$ & $\begin{array}{l}52(27.96) \\
30(16.13) \\
52(27.96) \\
52(27.96)\end{array}$ & $\begin{array}{l}32(26.9) \\
20(16.8) \\
33(28.4) \\
34(65.4)\end{array}$ & $\begin{array}{l}20(29.9) \\
10(14.9) \\
19(28.4) \\
18(26.9)\end{array}$ & 0.964 \\
\hline
\end{tabular}




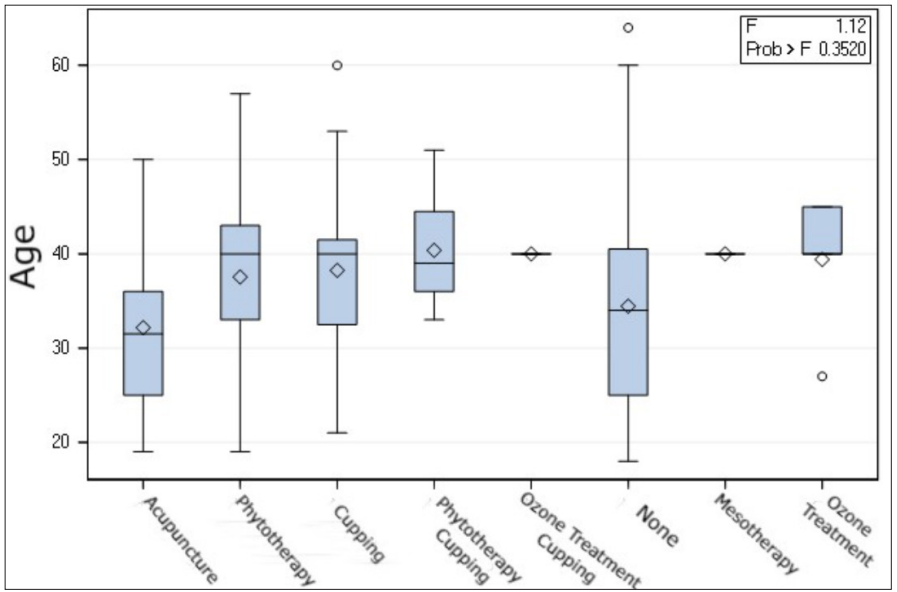

Graphic 1. Early complication rate

Participants' views and attitudes on TCM practices in the COVID-19 outbreak are given in Table 3. Phytotherapy $(22 \%, 46 \%)$ was the second cup treatment $(12.83 \%)$. Female participants were more likely to believe that TCM practices were beneficial for COVID-19 prevention and treatment $(p=0.04)$. At the same time, $27.7 \%$ of respondents thought TCM would be no more beneficial than conventional COVID-19 drugs, while $19.79 \%$ believed it would be beneficial with routine medications.

\begin{tabular}{|c|c|c|c|c|}
\hline \multirow{2}{*}{ Survey Questions } & \multicolumn{4}{|c|}{ Answers n (\%) } \\
\hline & Yes & Partially & Undecided & No \\
\hline $\begin{array}{l}\text { Do you believe that TCM } \\
\text { practices are useful to protect } \\
\text { against COVID-19 or to cure the } \\
\text { disease? }\end{array}$ & $\begin{array}{c}53 \\
(28.34)\end{array}$ & $\begin{array}{c}47 \\
(25.13)\end{array}$ & $\begin{array}{c}61 \\
(32.62)\end{array}$ & $\begin{array}{c}26 \\
(13.90)\end{array}$ \\
\hline $\begin{array}{l}\text { Do you believe that TCM } \\
\text { practices are more beneficial in } \\
\text { the treatment of COVID- } 19 \text { than } \\
\text { the drugs used for the disease? }\end{array}$ & $\begin{array}{c}27 \\
(14.44)\end{array}$ & $\begin{array}{c}44 \\
(23.53)\end{array}$ & $\begin{array}{c}65 \\
(34.76)\end{array}$ & $\begin{array}{c}51 \\
(27.27)\end{array}$ \\
\hline $\begin{array}{l}\text { Do you believe that getting TCM } \\
\text { practices together with drugs in } \\
\text { the treatment of COVID-19 will } \\
\text { better treat the disease? }\end{array}$ & $\begin{array}{c}37 \\
(19.79)\end{array}$ & $\begin{array}{c}61 \\
(32.62)\end{array}$ & $\begin{array}{c}57 \\
(30.48)\end{array}$ & $\begin{array}{c}32 \\
(17.11)\end{array}$ \\
\hline
\end{tabular}

\section{DISCUSSION}

With the onset of the coronavirus pandemic, intensive studies on COVID-19 treatment and prevention methods continue to be carried out all over the world. Although proven vaccines have been widely applied for prevention, the treatment options currently proven effective in the treatment of COVID-19 are unclear. ${ }^{[10,11]}$ Therefore, there has been increased interest in both classical TCM practices in order to protect against COVID-19. ${ }^{[12-15]}$

In this study, we aimed to evaluate the knowledge, awareness, and attitudes of patients with suspected COVID-19 about TCM. It was generally previously thought that the perspective on TCM practices was lower and the belief was more less. ${ }^{[16]}$ However, we found that most (77.5\%) of respondents had knowledge of TCM practices and believed in TCM practices (71.7\%). In addition, it was found that the level of knowledge about TCM practices was similar between education and sociocultural levels among the participants. For this reason, we see that TCM practices are now homogeneously distributed in society and that there is an increasing interest in TCM practices by the whole society regardless of profession and education.

During the pandemic period, the positive integrative effects of TCM practices, especially phytotherapy and ozone treatment, on classical medicine in the treatment of COVID-19 have been proven. ${ }^{[1,1]]}$ In our study, although phytotherapy was most used in the prevention and treatment of COVID-19, it was found that the participants did not show the appropriate rates of interest in the literature in ozone treatment. Interestingly, although there were no studies evaluating the effectiveness of cup therapy in the treatment and protection of COVID-19, it was determined that the participants applied increasing interest in cup treatment. We think that the reason for this situation is that cup treatment is the most common TCM practices and because the positive effects of cup treatment on the immune system are known to society, it is a frequently used method.

A few studies was reported that acupuncture treatment has anti-inflammation, immunity activation and nervous system modulation were primary therapeutic pathways of acupuncture against COVID-19. ${ }^{[18-20]}$ In addition, it has been claimed that acupuncture treatment relieves symptoms associated with COVID-19 and has an effect on relieving symptoms associated with anxiety after COVID-19 treatment. ${ }^{[19,21]}$ However, more studies are needed to prove the effects of acupuncture on COVID-19 treatment. Acupuncture therapy has not become widespread in society, despite its everincreasing trend. In our study, 39 (20.8\%) of the participants stated that they knowed to acupuncture and only $4.8 \%$ of them reported that they applied to it. Therefore, there is a need to raise awareness of the effectiveness of acupuncture in the treatment of COVID-19 in the society.

It was previously reported that women's attitudes to TCM practices were more positive. ${ }^{[22,23]}$ In this study, it is seen that awareness of TCM practices in the treatment of COVID-19 and protections more positive in middle-aged women and supports the literature. Complementary medicine treatments are widely accepted in adults today. Especially in the last two decades, studies on TCM have gained momentum all over the world and their effective results have been accepted. Complementary medicine offered people opportunities for both regression of functional complaints and anti-aging effects. Functional complaints (sweating, palpitations, fatigue and anxiety, etc.) and aging anxiety are frequently observed in middle-aged women in the perimenopausal period. For this reason, we think that middle-aged women are more aware of TCM and they resort to those treatments more frequently.

More than half $(53.47 \%)$ of respondents believe that TCM practices are partially or completely beneficial in COVID-19 recovery. However, most participants (27.27\%) also confirmed that it was no more effective than conventional medical 
treatments. Nevertheless, it is more accepted that it is useful for the purpose of complementary treatment of classical medicine (52.41\%). Therefore, it shows that society applied TCM practices as holistic treatment during the pandemic period and believes that it would be more beneficial to treat COVID-19 with a holistic approach.

The fact that TCM practices are believed to be beneficial for health $(50.27 \%)$ and that TCM practices are beneficial for the prevention of COVID-19 disease or for the recovery of the disease (28.24\%) may be due to the fact that TCM practices are not yet widely used in the holistic treatment of COVID-19. Therefore, holistic treatment results are needed in the near future.

\section{CONCLUSION}

This study was conducted at a time when COVID-19 pandemic cases were intense in Turkey and revealed awareness, attitudes and behaviors about TCM practices of participants at risk of COVID-19, although they have limitations in terms of representation and generalization. Although TCM practices have become very common in our country, the importance of holistic approaches to protection from COVID-19 and the improvement of the disease has not yet reached sufficient prevalence in society.

\section{ETHICAL DECLARATIONS}

Ethics Committee Approval: Ethical approval numbered 2021/005 was obtained from KTO Karatay University.

Informed Consent: Because the study was designed retrospectively, no written informed consent form was obtained from patients.

Referee Evaluation Process: Externally peer-reviewed.

Conflict of Interest Statement: The author(s) declared no potential conflicts of interest with respect to the research, authorship, and/or publication of this article.

Financial Disclosure: The authors declared that this study has received no financial support.

Author Contributions: All of the authors declare that they have all participated in the design, execution, and analysis of the paper, and that they have approved the final version.

\section{REFERENCES}

1. İkizek M, Uzuntarla Y. Medical Ozone Therapy and COVID-19. Sag Aka Derg 2020;7(4):304-10.

2. Portella CFS, Ghelman R, Abdala CVM, Schveitzer MC. Evidence map on the contributions of traditional, complementary and integrative medicines for health care in times of COVID-19. Integr Med Res 2020;9(3):100473.

3. Ganguly S, Bakhshi S. Traditional and complementary medicine during COVID-19 pandemic. Phytother Res 2020;34(12):3083-4.

4. Huang $\mathrm{KY}$, Chang $\mathrm{CH}$, Hsu CH. The efficacy of acupuncture for improving the side effects of COVID-19 western medicine treatments:A protocol for a systematic review and meta-analysis. Medicine (Baltimore) 2020;99(28):e21185.
5. Cattel F, Giordano S, Bertiond C, et al. Ozone therapy in COVID-19:A narrative review. Virus Res 2021;291:198207.

6. Martínez-Sánchez G, Schwartz A, Donna VD. Potential Cytoprotective Activity of Ozone Therapy in SARS-CoV-2/COVID-19. Antioxidants (Basel) 2020;9(5):389.

7. Arreola R, Quintero-Fabián S, López-Roa Rl, et al. Immunomodulation and anti-inflammatory effects of garlic compounds. J Immunol Res 2015;2015:401630.

8. Ahmed S, Rahman A, Hasnain A, Lalonde M, Goldberg VM, Haqqi TM. Green tea polyphenol epigallocatechin-3-gallate inhibits the IL-1 betainduced activity and expression of cyclooxygenase- 2 and nitric oxide synthase-2 in human chondrocytes. Free Radic Biol Med 2002;33(8):1097.

9. Han YS, Chang GG, Juo CG, et al. Papain-like protease 2 (PLP2) from severe acute respiratory syndrome coronavirus (SARS-CoV):expression, purification, characterization, and inhibition. Biochemistry 2005;44(30):10349-59

10. Izda V, Jeffries MA, Sawalha AH. COVID-19:A review of therapeutic strategies and vaccine candidates. Clin Immunol 2021;222:108634.

11. Stasi C, Fallani S, Voller F, Silvestri C. Treatment for COVID-19:An overview. Eur J Pharmacol 2020;889:173644.

12. Bae M, Kim H. Mini-Review on the Roles of Vitamin C, Vitamin D, and Selenium in the Immune System against COVID-19. Molecules 2020;25(22):5346.

13. Shakoor $\mathrm{H}$, Feehan J, Al Dhaheri AS, et al. Immune-boosting role of vitamins $D, C, E$, zinc, selenium and omega-3 fatty acids:Could they help against COVID-19? Maturitas 2021;143:1-9.

14. Wu L, Yuan Q, Kuang Y, et al. External treatment of traditional Chinese medicine for COVID-19:A protocol for systematic review and metaanalysis. Medicine (Baltimore) 2020;99(39):e22316.

15. Alschuler L, Weil A, Horwitz R, et al. Integrative considerations during the COVID-19 pandemic. Explore (NY) 2020;16(6):354-6.

16. Ergin A, Hatipoğlu C, Bozkurt Al, et al. Knowledge and attitudes of residents and medical students on complementary-alternative medicine. Pamukkale Med J 2011;4:136-43.

17. Liu M, Gao Y, Yuan Y, et al. Efficacy and Safety of Integrated Traditional Chinese and Western Medicine for Corona Virus Disease 2019 (COVID-19):a systematic review and meta-analysis. Pharmacol Res 2020;158:104896.

18. Wen $D, W u L$, Dong $Y$, et al. The effect of acupuncture on the quality of life of patients recovering from COVID-19:A systematic review protocol. Medicine (Baltimore) 2020;99(30):e20780.

19. Han Z, Zhang Y, Wang $P$, et al. Is acupuncture effective in the treatment of COVID-19 related symptoms? Based on bioinformatics/network topology strategy. Brief Bioinform. 2021 Apr 19:bbab110. doi:10.1093/ bib/bbab110. Epub ahead of print.

20.Sun P, Zhou SW. Acupuncture in the Treatment of COVID-19:An Exploratory Study. J Chin Med. 2020;6:1-7.

21. Huang $\mathrm{KY}$, Chang $\mathrm{CH}$, Hsu $\mathrm{CH}$. The efficacy of acupuncture for improving the side effects of COVID-19 western medicine treatments:A protocol for a systematic review and meta-analysis. Medicine (Baltimore). 2020;99(28):e21185.

22. Erci B. Attitudes towards holistic complementary and alternative medicine:a sample of healthy people in Turkey. J Clin Nurs. 2007;16(4):7618.

23. Özcan N, İyisoy MS. Investigation of the Knowledge and Attitude of Faculty Members About Traditional and Complementary Medicine Applications. J Tradit Complem Med 2020; 3(2):160-5. 